\title{
Assessing the Chemical Status of Water from Wells Which Supply Farms Located on Romania's Territory. Part I
}

\author{
Cristina EL MAHDY ${ }^{1 *}$, Silvana POPESCU ${ }^{2}$, Anca BOARU ${ }^{1}$, Cristin BORDA ${ }^{2}$ \\ ${ }^{1}$ Faculty of Animal Husbandry and Biotechnologies,University of Agricultural Sciences and Veterinary \\ Medicine, Calea Mănăștur street 3-5, Cluj-Napoca, România \\ ${ }^{2}$ Faculty of Veterinary Medicine' University of Agricultural Sciences and Veterinary Medicine, Calea \\ Mănăştur street 3-5, Cluj-Napoca România \\ * corresponding author: cristina.hegedus@usamvcluj.ro
}

Bulletin UASVM Animal Science and Biotechnologies 73(2)/ 2016

Print ISSN 1843-5262; Electronic ISSN 1843-536X

DOI:10.15835/buasvmcn-asb: 12154

\begin{abstract}
Aim of this study was to assess the chemical status of water by point of view of the indicators parameters coming from the decentralized system of water supply (wells) and which supply with water the dairy cows farms. Study was performed in 63 wells from the same number of farms from 5 counties located in: S-E, N-W and central of Romania at the request of farmers. It has been studied the parameters that indicate the status of water acidification: pH (SR ISO 10523:1997); indicator parameters having as landmark the minimum list of parameters monitored by the laboratories of profile from county public health department: hardness (STAS 3326:1976), iron (STAS 3086:1968), CCOMn (STAS: 3002:1985), ammonia (spectrometry), parameters indicative of saline inclusions: chlorides (STAS 3049:1988), sulfates (SR ISO 10523:1997). Characterization of the chemical state of water: good or poor was done after the values that define the worst condition. The limit values for each parameter are compared to those required by the L.107/1996, L.458/2002, 311/2004, Order 621/2012. Were recorded values which attesting good quality status for 21 wells:[ 1 Buzău (BZ),12 Cluj (CJ),2 Mureș (MS),6 Sălaj (SJ)] and 42 wells whose water quality status it is poor ( $6 \mathrm{AB}, 5 \mathrm{BZ}, 17 \mathrm{CJ}, 7 \mathrm{MS})$. Exceeding the limits values were found at the parameters: CCOMn (CJ: $\left.05.29 \pm 3.87 \mathrm{mgO}_{2} / \mathrm{dm}^{3}, 10.59 \pm 2.04 \mathrm{mgO}_{2} / \mathrm{dm}^{3} \mathrm{AB}\right)$; ammonia: $\left(\mathrm{AB}: 0.56 \pm 0.08 \mathrm{mg} / \mathrm{dm}^{3}\right.$, MS: $0.51 \pm 0.1 \mathrm{mg} / \mathrm{dm}^{3}$ ), iron (BZ: $0.85 \pm 1.05 \mathrm{mg} / \mathrm{dm}^{3}$, CJ: $0.37 \pm 0.47 \mathrm{mg} / \mathrm{dm}^{3}$, MS: $0.62 \pm 0.57 \mathrm{mg} / \mathrm{dm}^{3}$ ), chlorides (AB: $330.42 \pm 208.8 \mathrm{mg} / \mathrm{dm}^{3}$, MS: $243.18 \pm 164.8 \mathrm{mg} / \mathrm{dm}^{3}$ ). Contamination risk score of wells in the studied areas is medium (3 point).
\end{abstract}

Keywords: Chemical states, cow, drinking water

\section{INTRODUCTION}

The study consisted in assessing the chemical status of water by point of view of the indicators parameters coming from the decentralized system of water supply (wells) from 63 wells from the same number of farms located in 5 different counties and which supply water for dairy cows farms. Romania belongs to the countries with medium quantities of water because not all underground water can be considered sources of drinking water and some groundwater are located at very large depths with no possibility of being used (Man, 2007). As a result, annual water resources are only by $1.700 \mathrm{~m}^{3} /$ inhabitant compared with other European countries where the reserves are on the average with 2.5 times higher (http://www.anpm.ro,). In the National System of Integrated Monitoring it is pursuing 6 subsystems: of which ground waters (art.2, Order. 31/2006). By groundwaters is meant all water which is under surface of the soil (EU Water Directive 2000/60/CE). In Romania in 2013 theoretical groundwater resource was 9.600 .000 thousands $\mathrm{m}^{3}$ from which: phreatic waters had an intake of 4.700 .000 thousands $\mathrm{m}^{3}$ and 
underground by 4.900 .000 thousands $\mathrm{m}^{3}$, the used sources having a value of 4.667 .639 thousands $\mathrm{m}^{3}$ in 2014 (Moldovan C. et al, 2014) and 5.411.322 thousands $\mathrm{m}^{3}$ in 2015 (SOER quide, 2015). About $30 \%$ the population is supplied with water from individual sources: individual or public wells, or water provided after drilling (boreholes) (http:// www.posmediu.ro, 2013). In terms of quality, phreatic water is considered clean and potable, fall in standards or industrial uses less pretentious (Muntean et al., 2009), but some underground water quality problems can be associated with changing parameters: organoleptic, physical temperature, and of the chemical: $\mathrm{pH}$, alkalinity, sulfate, TDS, iron, manganese, chloride (Braul L. et al, 2001) or the water quality can be denatured either due to of nature telluric of soil or a result of contamination (El Mahdy, 2013). Like humans," all animals must have access to a suitable water source" (Order no.75/2005).

\section{MATERIALS AND METHODS}

Qualitative assessment of the chemical status was performed to 63 phreatic waterbodies from 5 counties located in S-E, NW-eastern and center of Romania: Alba (AB- localization: central part of Romania: 7 wells), Buzău (BZ- localization: S-E: 6 wells), Cluj (CJ localization: central west: 33 wells), Mureș (MS- localization: central - northern: 11 wells), Sălaj (SJ - localization: northwest: 6 wells)] used as source of drinking water for watering cattle. Samples collected were sent by courier in freezer bags or containers surrounded by ice and analyzes were performed immediately at receiving the package. Had been taking in the study between compulsory parameters: pH (SR ISO 10523:1997) and indicator parameters having as landmark minimum list of parameters monitored by laboratories profile from public health department from the county: CCOMn (STAS: 3002:1985, volumetric), ammonia (spectrometry), hardness (STAS 3326:1976, volumetric), iron (STAS 3086:1968), parameters indicative of saline intrusion: chlorides (STAS 3049:1988), sulfates (SR ISO 10523:1997). The period in which samples were analyzed took place in 2015, when, after balancing feed rations, milk production has not achieved the expected level. In order for a waterbodies (wells) to be considered to have good state by point of view qualitative the value of the parameters stud- ied at the well had not to exceed $20 \%$ the one or more analyzed parameters compared to the reference value (Water Framework Directive 2000/60/ EC, 2006/118/CE, the Order of 621/2014). Over this percentage, the chemical state of waterbody was considered to be poor. It was used as statistical tests accepted for water (Helsel DR et al, 2002): parametric tests: T test, non parametric test Krushall-Wallis dependent on expansion of values on Gaussian curve, and comparing the obtained values after a established value (Fisher's Test), by Law 458/2002 and "guide for completing the inspection notes concerning animal protection and welfare". Sanitary evaluation of the wells taken in study was performed based on the score of risk of contaminating public wells (Iacob 0 et al., 2012), taking as a basis for assessing the risk of contamination nonconformities observed according to the 8 criteria followed each explained in Order no.119/2014 Chapter III, art.2 (2) and depending on which criteria are ticked with YES or NO. Depending on the number of nonconformities is granted the score indicating the degree of risk.

\section{RESULTS AND DISCUSSION}

In the studied areas, the sources of pollution are ubiquitous: nonconformity, but the distance between shelters, manure platforms is higher than $10 \mathrm{~m}$ compared with water sources not under this distance: conformable. The construction of wells is appropriate, the walls being from concrete with variable diameter $0.8-1.5 \mathrm{~m}$ : conformable, whose height is by $0.7 \mathrm{~m}$ and more in some situations compared to the ground: conformable. The wells are not located under the trees which represents a lack of conformity in accordance with the requirements, but are protected at exposure at weather and rainfall through a rudimentary roof: conformable.

The way in which the water is brought in drinking troughs is based on financial possibilities of the farmer with water pump or hydrophore: conformable. Not in all cases are satisfied the conditions related to location of the wells: slope or surrounded by protection zone paved or cemented: nonconformity. Quantifying all aspects that indicate nonconformities, contamination risk score is 3 , meaning medium. From discussions with farmers has not been found during the years quantitative deficiencies in water supply of farms, 
therefore the wells are located in areas with extremely low quantitative risk on this case.

From point of view of the state of water acidification was monitored $\mathrm{pH}$ parameter (table 1). Even if, individual values presents fluctuations characterizing water as being weak alkaline (7.0 unit pH AB-7.18 BZ,7.05 unit pH SJ), weakly acid (6.3 unit pH CJ-6.98 unit pH MS) with an ascendant curve of the values up to alkaline water in all cases, zonal mean values indicates good water, potable in terms of this parameter. Are not recorded significant differences between the obtained values (ns $\mathrm{P}>0.05$ ). From total number of analyzed samples only one sample was identified with a $\mathrm{pH}$ value which does not fall within accepted limits (6.3.unit $\mathrm{pH} \mathrm{CJ}$ ). Animals farm supports variations of $\mathrm{pH}$ between 6.5-8.5 unit $\mathrm{pH}$ after Curran et al. (2007) and Olkowski (2009) considers that cattle prefer water with a $\mathrm{pH}$ between 6.0-8.0 unit. $\mathrm{pH}$. In terms of chemical status, 62 wells are included as having good quality of water at this parameter.

Poor chemical status in terms of iron parameter has been recorded in all wells from $\mathrm{BZ}$, where individual values have been ranged between: $0.30-2.99 \mathrm{mg} / \mathrm{dm}^{3}$, the mean value/ area being by $0.85 \pm 1.05 \mathrm{mg} / \mathrm{dm}^{3}$ (table 1 ). The same poor chemical status has been found in $\mathrm{CJ}$, where the mean was by $0.37 \pm 0.47 \mathrm{mg} / \mathrm{dm}^{3}$. From 33 analyzed samples in 12 samples (39.39\%) were noted exceedances of maximum admissible concentrations, individual values ranging from 0.25 to $2.48 \mathrm{mg} / \mathrm{dm}^{3}$. In MS, from 11 samples subjected to the analysis, 8 of these exceed the standard limit at iron parameter which means $72.72 \%$ and designates the overall poor chemical status of waterbodies in terms of this parameter. The average value in MS area is by $0.62 \pm 0.57$ $\mathrm{mg} / \mathrm{dm}^{3}$ and fluctuations in individual values ranging from 0.01 to $2.01 \mathrm{mg} / \mathrm{dm}^{3}$. After Linn J. (2013) cows can tolerate water containing up to $4 \mathrm{mg} / \mathrm{dm}^{3} \mathrm{Fe}$, but at about $2 \mathrm{mg} / \mathrm{l}$ affect sensory characteristics of milk.

Overruns at iron parameter are recorded also in SJ area: $0.21-0.26 \mathrm{mg} / \mathrm{dm}^{3}$, but the values are closer by standard value $\left(0.2 \mathrm{mg} / \mathrm{dm}^{3}\right)$. The chemical status by point of view of this parameter the water is good, $0.26 \mathrm{mg} / \mathrm{dm}^{3}$ having local character and does not exceed the value of 0.3, which, after Swistock B. (2012) induce an unpleasant taste of the water, and decreases the voluntarily consumption of water coupled with decreasing milk production. Have not noted nonconformities in terms of iron parameter in $\mathrm{AB}$ where the obtained mean was by $0.05 \pm 0.02 \mathrm{mg} /$ $\mathrm{dm}^{3}$, and chemical status considered good, $100 \%$ from results having values under maximum allowed concentration: 0.01-0.09 $\mathrm{mg} / \mathrm{dm}^{3}$. From statistical point of view are notice distinct significant differences $\left({ }^{* *} \mathrm{P}<0.01\right)$ between the mean values obtained in $A B$ with those from $\mathrm{BZ}$ and $\mathrm{MS}$, and significant between $\mathrm{AB}$ and $\mathrm{CJ}$ $\left({ }^{*} \mathrm{P}<0.05\right)$. Between the other counties differences are insignificant (ns $\mathrm{P}>0.05$ ).

Water hardness (TH). From the total number of samples (63), the water administered to animals in terms of hardness parameter is presented as follows (table 3): 13 samples (21\%) falls in soft water, 7 samples (11\%) semi-hard water, 35 samples (56\%) hard water and 8 samples (13\%) falls into the category very hard water. In $A B$,

Tab. 1. The mean of obtained value at parameters $\mathrm{pH}$ and iron /counties

\begin{tabular}{|c|c|c|c|c|c|c|c|c|c|c|}
\hline \multirow{2}{*}{$\begin{array}{l}\vec{\Xi} \\
\Xi \\
0\end{array}$} & \multicolumn{4}{|c|}{ Mean of $\mathrm{pH}$ value } & \multirow{2}{*}{ 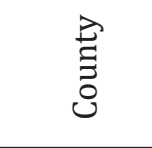 } & \multicolumn{5}{|c|}{ Mean of iron value } \\
\hline & No.S. & $\begin{array}{c}\mathrm{X} \pm \mathrm{sd} \\
\mathrm{mg} / \mathrm{dm}^{3}\end{array}$ & Min & Max & & $\begin{array}{c}\mathrm{X} \pm \mathrm{sd} \\
\mathrm{mg} / \mathrm{dm}^{3}\end{array}$ & $\mathrm{BZ}$ & CJ & MS & SJ \\
\hline $\mathrm{AB}$ & 7 & $7.65 \pm 0.63$ & 7.00 & 8.84 & $\mathrm{AB}(7 \mathrm{~S})$ & $0.05 \pm 0.02$ & $* * \mathrm{P}<0.01$ & ${ }^{*} \mathrm{P}<0.05$ & ${ }^{* *} \mathrm{P}<0.01$ & $n s P>0.05$ \\
\hline $\mathrm{BZ}$ & 6 & $7.64 \pm 0.29$ & 7.18 & 8.00 & $\mathrm{BZ}(6 \mathrm{~S})$ & $0.85 \pm 1.05$ & - & ns $>0.05$ & $\mathrm{nsP}>0.05$ & $n s P>0.05$ \\
\hline $\mathrm{CJ}$ & 33 & $7.40 \pm 0.53$ & 6.30 & 8.36 & CJ (33S) & $0.37 \pm 0.47$ & - & - & $\mathrm{nsP}>0.05$ & $n s P>0.05$ \\
\hline MS & 11 & $7.50 \pm 0.54$ & 6.98 & 8.93 & MS(11S) & $0.62 \pm 0.57$ & - & - & - & $n s P>0.05$ \\
\hline SJ & 6 & $7.77 \pm 0.56$ & 7.05 & 8.30 & SJ (6S) & $0.20 \pm 0.04$ & & & & \\
\hline \multicolumn{11}{|c|}{ Legend:Alba (AB), Buzau(BZ), Cluj (CJ), Mures (MS), Sălaj(SJ ), } \\
\hline
\end{tabular}


$57 \%$ (4) from the analyzed samples indicate hard water and $43 \%$ (3) very hard water, mean per area: $29.87 \pm 6.34^{\circ} \mathrm{G}$, with fluctuations in individual values ranging between $22.4-41^{\circ} \mathrm{G}$.

In terms of limits established by Law $458 / 2002$, water hardness must to have at least $5^{0} \mathrm{G}$, but is not specified the superior level. The effect of hard water exerted on animal organism is still a controversial topic. Sometimes can affect health status of animals or compromising the milk quality by decreasing the percentage of fat milk (El Mahdy, 2013). In descending order, water with high hardness (hard) also, were found in the samples taken from wells from SJ county, where the mean $25.53 \pm 6.31^{\circ} \mathrm{G}$ indicate hard water, but, individual analysis shows that $67 \%$ (4) from samples falls in the category of water with high hardness, and $33 \%$ (2) from samples have very high hardness; individual values having an ascendant curve, between $17.9-33.3^{\circ} \mathrm{G}$ (table 2). The third place in the top of waters with high hardness is assigned to $\mathrm{BZ}$, where, $100 \%$ from analyzed samples have the hardness ranging between $16.8-28.6^{\circ} \mathrm{G}$ and an average of $22.11 \pm 3.95^{\circ} \mathrm{G}$. Between those three areas are not found significant differences statistically (ns P>0.05). Although, the water samples analyzed from MS and CJ counties indicates hard water, individual waterbodies reveal variations. In CJ county, were obtained 27\% (9) from samples as having soft water, $12 \%$ (4) semihard water, 55\% (18) hard water and 6\% (2) from samples, very hard water, the mean: $15.44 \pm 8.76^{\circ} \mathrm{G}$. In MS county $36 \%$ (4) from samples enter into soft waters category, $27 \%$ semi-hard water, $27 \%$ hard water and $9 \%$ very hard water, mean being by $14.21 \pm 12.9^{\circ} \mathrm{G}$. It may be noted, however, that, on areas of the same county there is a huge discrepancy of the values compared to Gaussian distribution: minimum 4.48-maximum $47.1^{\circ} \mathrm{G}$ CJ and $4.9-49.2^{\circ} \mathrm{G}$ - MS. From statistical point of view between those two areas there is not significant difference statistically but it can be found distinct significant differences $\left({ }^{* *} \mathrm{P}<0.01\right)$ between $\mathrm{AB}$ compared with $\mathrm{CJ}$ and MS counties. After German et al. (2008), hardness has no effect on water safety, but, high concentrations of minerals, usually those associated with water hardness, can lead to precipitation of salts in the equipment and watering system, which affects flow rates or,

Tab. 2. Mean obtained to parameter hardness/counties

\begin{tabular}{ccccccccccc}
\hline County & No.S. & $\mathrm{X} \pm \mathrm{sd}$ & $\mathrm{V} \%$ & Min & Max. & County & BZ & $\mathrm{CJ}$ & MS & SJ \\
\hline $\mathrm{AB}$ & 7 & $29.87 \pm 6.3$ & 21.2 & 22.4 & 41.3 & $\mathrm{AB}$ & $\mathrm{ns} \mathrm{P}>0.05$ & ${ }^{* *} \mathrm{P}<0.01$ & ${ }^{* *} \mathrm{P}<0.01$ & $\mathrm{nsP}>0.05$ \\
\hline $\mathrm{BZ}$ & 6 & $22.11 \pm 3.9$ & 17.8 & 16.8 & 28.6 & $\mathrm{BZ}$ & - & $\mathrm{nsP}>0.05$ & $\mathrm{~ns} \mathrm{P}>0.05$ & $\mathrm{nsP}>0.05$ \\
\hline $\mathrm{CJ}$ & 33 & $15.44 \pm 8.7$ & 56.0 & 4.4 & 47.1 & $\mathrm{CJ}$ & - & - & $\mathrm{ns} \mathrm{P}>0.05$ & $\mathrm{nsP}>0.05$ \\
\hline $\mathrm{MS}$ & 11 & $14.21 \pm 12.9$ & 84.4 & 4.9 & 49.2 & MS & - & - & - & $\mathrm{nsP}>0.05$ \\
\hline SJ & 6 & $25.53 \pm 6.3$ & 24.7 & 17.9 & 33.3 & SJ & $\begin{array}{c}\text { KWt, KW }=23.859, \mathrm{P}=<0.0001, \text { extremely } \\
\text { significant, } \\
\text { sd }{ }^{*} \mathrm{P}-\text { distinct significant, }\end{array}$ \\
\hline
\end{tabular}

Tab. 3. Degree of hardness of samples analyzed/counties (Fisher's Test)

\begin{tabular}{ccccccc}
\hline \multirow{2}{*}{$\begin{array}{c}\text { Area } \\
\text { from samples }\end{array}$} & \multicolumn{5}{c}{ Fisher's Test } \\
\cline { 3 - 7 } & $\begin{array}{c}\text { Soft water } \\
4-8^{\circ} \mathrm{G}\end{array}$ & $\begin{array}{c}\text { Semi-hard } \\
\text { water } 8-12^{\circ} \mathrm{G}\end{array}$ & $\begin{array}{c}\text { Hard water } \\
12-30^{\circ} \mathrm{G}\end{array}$ & $\begin{array}{c}\text { Very hard water } \\
\text { over } 30^{\circ} \mathrm{G}\end{array}$ & P value \\
\hline $\mathrm{AB}$ & $11.11 \%$ & - & - & $57 \%(4)$ & $43 \%(3)$ & 0.028 , significant \\
\hline $\mathrm{BZ}$ & $9.52 \%$ & - & - & $100 \%(6)$ & - & - \\
\hline $\mathrm{CJ}$ & $52.38 \%$ & $27 \%(9)$ & $12 \%(4)$ & $55 \%(18)$ & $6 \%(2)$ & 0.18, not significant \\
\hline $\mathrm{MS}$ & $17.46 \%$ & $36 \%(4)$ & $27 \%(3)$ & $27 \%(3)$ & $9 \%(1)$ & 1.0 not significant \\
\hline $\mathrm{SJ}$ & $9.52 \%$ & - & - & $67 \%(4)$ & $33 \%(2)$ & 0.06 not significant \\
\hline $\mathrm{T}$ & $100 \%$ & $21 \%(13)$ & $11 \%(7)$ & $56 \%(35)$ & $13 \%(8)$ & 0.005 extremely significant
\end{tabular}

Legend:Alba (AB), Buzau(BZ), Cluj (CJ), Mures (MS), Salaj(SJ), KWt- Kruskal-Wallis Test, No samples (No.S.), Total (T) 
can clog completely the drinker lines through the accumulation of chalk (El Mahdy, 2013).

Chemical oxygen demand (CCOMn) it is the parameter that belongs to the category of oxygen regime indicators. Regarding the CCOMn parameter can not say that water is sanogenic in all studied wells (table 4).

Compared with the treshold values estabilish for this parameter $\left(\max .5 \mathrm{mg} \mathrm{O}_{2} / \mathrm{dm}^{3}\right)$ : $42.85 \%$ (3) from samples analyzed in $A B$ have CCOMn values ranging between $5-10 \mathrm{mg} \mathrm{O}_{2} / \mathrm{dm}^{3}$ (7.5-9.7 mg $\mathrm{O}_{2} / \mathrm{dm}^{3}$ ) and $57.14 \%(4)$ over $10 \mathrm{mg} \mathrm{O}_{2} / \mathrm{dm}^{3}$ (10.3-13.75 $\mathrm{mg} \mathrm{O}_{2} / \mathrm{dm}^{3}$ ) which does not include water in the potability standards. The mean/area: $10.59 \pm 2.04 \mathrm{mg} \mathrm{O}_{2} / \mathrm{dm}^{3}$ indicates poor chemical status of water; individual values exceeding the limit by more than 20\%. Assesing waterbodies from BZ indicates good water in terms of this parameter, in all 6 wells the results being under $5 \mathrm{mg} \mathrm{O}_{2} / \mathrm{dm}^{3}(2.12 \pm 1.23)$, the curve of individual values ranging between: $0.63-2.05 \mathrm{mg} \mathrm{O}_{2} / \mathrm{dm}^{3}$. Exceedances of maximum admitted limits for this parameter are recorded in CJ, where: from total number of analyzed samples (33-100\%), 33.33\% - 11 samples shows fluctuations ranging between 5-10: 5.91-9.19 $\mathrm{mg} \mathrm{O}_{2} / \mathrm{dm}^{3}$ and 9.09\% -3 samples, over $10 \mathrm{mg} \mathrm{O}_{2} / \mathrm{dm}^{3}: 11.82-15 \mathrm{mg} \mathrm{O}_{2} / \mathrm{dm}^{3}$. Only
$57.57 \%$ (19) from samples enroll in drinkability limits and good chemical status. The mean/area is by $5.29 \pm 3.87 \mathrm{mg} \mathrm{O}_{2} / \mathrm{dm}^{3}$ which indicates poor chemical status of water from the peripheral area of CJ county, used as a watering source for dairy cows. Average under allowed limit: $4.56 \pm 3.62 \mathrm{mg}$ $\mathrm{O}_{2} / \mathrm{dm}^{3}$ was obtained in the analyzed samples from MS. Nevertheless, individual results in $45.45 \%$ (5) from samples have values between 5.5-9.93 $\mathrm{mg} \mathrm{O}_{2} / \mathrm{dm}^{3}$, which means that exceed the allowed limits. In SJ from 6 wells, 5 (83.83\%) of samples get into category of drinkability limits and good chemical status (2.5-3.55 $\mathrm{mg} \mathrm{O}_{2} / \mathrm{dm}^{3}$ ); in one sample is reveals a very slight exceeded than the threshold value 5.01, but fall into good chemical status because the overrun is less than $20 \%$. The mean/area: $3.23 \pm 0.95 \mathrm{mg} \mathrm{O}_{2} / \mathrm{dm}^{3}$. Regarding this parameter, samples taken from territory of $\mathrm{AB}$ county have the greatest degree of contamination with organic matter which entails the distinct significant differences $\left({ }^{* *} \mathrm{P}<0.01\right)$ compared to analyzed samples from BZ where, $100 \%$ from samples have values under allowed limits, and significant $\left({ }^{*} \mathrm{P}<0.05\right)$ between $\mathrm{AB}: \mathrm{CJ}$ and MS. Not significant differences were found between the values obtained from the other counties. Not significant differences were found

Tab. 4. Mean obtained to parameter of oxygen regime: CCOMn/counties and the percentage of wells with varying degrees of contamination

\begin{tabular}{|c|c|c|c|c|c|c|c|c|c|}
\hline \multirow[t]{2}{*}{ 总 } & \multirow[t]{2}{*}{$\begin{array}{l}\text { No.S. } \\
(\%)\end{array}$} & \multirow{2}{*}{$\begin{array}{l}\text { KWt } \\
\mathrm{X} \pm \mathrm{sd}\end{array}$} & \multicolumn{3}{|c|}{$\begin{array}{l}\text { Value of CCO Mn, no of } \\
\text { samples and \% for each } \\
\text { degree of impurification } \\
\text { (Fisher's test) }\end{array}$} & \multirow[t]{2}{*}{$\begin{array}{l}己 \\
\Xi \\
0\end{array}$} & \multirow[t]{2}{*}{ BZ } & \multirow[t]{2}{*}{ CJ } & SJ \\
\hline & & & Under 5 & $\begin{array}{c}\text { Between } \\
5-10 \\
\end{array}$ & $\begin{array}{l}\text { Up to } \\
10 \\
\end{array}$ & & & & \\
\hline $\mathrm{AB}$ & $\begin{array}{c}7 \\
11.11 \% \\
\end{array}$ & $10.59 \pm 2.04$ & $\begin{array}{c}0 \\
0 \% \\
\end{array}$ & $\begin{array}{c}3 \\
42.85 \% \\
\end{array}$ & $\begin{array}{c}4 \\
57.14 \% \\
\end{array}$ & $\mathrm{AB}$ & $* * \mathrm{P}<0.01$ & $* \mathrm{P}<0.05$ & $* \mathrm{P}<0.05$ nsP $>0.05$ \\
\hline $\mathrm{BZ}$ & $\begin{array}{c}6 \\
9.52 \% \\
\end{array}$ & $\begin{array}{r}2.12 \\
\pm 1.23 \\
\end{array}$ & $\begin{array}{c}6 \\
100 \% \\
\end{array}$ & $\begin{array}{c}0 \\
0 \% \\
\end{array}$ & $\begin{array}{c}0 \\
0 \% \\
\end{array}$ & $\mathrm{BZ}$ & - & $\mathrm{nsP}>0.05$ & $n s P>0.05 n s P>0.05$ \\
\hline CJ & $\begin{array}{c}33 \\
52.38 \% \\
\end{array}$ & $\begin{array}{r}5.29 \\
\pm 3.87 \\
\end{array}$ & $\begin{array}{c}19 \\
57.57 \% \\
\end{array}$ & $\begin{array}{c}11 \\
33.33 \% \\
\end{array}$ & $\begin{array}{c}3 \\
9.09 \% \\
\end{array}$ & CJ & - & - & $n s \mathrm{P}>0.05 \mathrm{nsP}>0.05$ \\
\hline MS & $\begin{array}{c}11 \\
17.46 \% \\
\end{array}$ & $\begin{array}{r}4.56 \\
\pm 3.62 \\
\end{array}$ & $\begin{array}{c}6 \\
54.54 \% \\
\end{array}$ & $\begin{array}{c}5 \\
45.45 \% \\
\end{array}$ & $\begin{array}{c}0 \\
0 \% \\
\end{array}$ & MS & - & - & $n s P>0.05$ \\
\hline SJ & $\begin{array}{c}6 \\
9.52 \% \\
\end{array}$ & $\begin{array}{r}3.23 \\
\pm 0.95 \\
\end{array}$ & $\begin{array}{c}5 \\
83.83 \% \\
\end{array}$ & $\begin{array}{c}1 \\
16.66 \% \\
\end{array}$ & $\begin{array}{c}0 \\
0 \% \\
\end{array}$ & SJ & & $\begin{array}{r}\text { t, KW-16.04 } \\
\text { very sign } \\
\end{array}$ & $\begin{array}{l}45, P=0.0030 \\
\text { nificant. }\end{array}$ \\
\hline $\begin{array}{l}\text { T.S } \\
\text { F.T }\end{array}$ & $\begin{array}{c}63 \\
100 \% \\
\end{array}$ & - & $\begin{array}{c}36 \\
57.14 \% \\
\end{array}$ & $\begin{array}{c}20 \\
31.75 \% \\
\end{array}$ & $\begin{array}{c}7 \\
11.11 \% \\
\end{array}$ & & $\begin{array}{r}\mathrm{P}=<0.00 \\
\text { very }\end{array}$ & $\begin{array}{l}01 \text {, extrem } \\
\text { significant, }\end{array}$ & $\begin{array}{l}\text { ely significant, }{ }^{* *} \mathrm{P}- \\
* \mathrm{P} \text { - significant }\end{array}$ \\
\hline
\end{tabular}


between the values obtained from the other counties. In 2007, in Someș Tisa basin, were obtained at the parameters: organic substances, nitrates, ammonia, total hardness the biggest overruns: (http://www.rowater.ro, 2007), while in 2014 in few cases were found overruns at these parameter (http://apmcj.anpm.ro, 2014), which suggests poor local management of the wells, by the absence of proper cleanliness, sanitation and disinfections, without affecting the entire aquifer.

Ammonia $\left(\mathbf{N H}_{3}\right)$. In descending order the mean values obtained to parameter ammonia are: $0.56 \pm 0.08 \mathrm{mg} / \mathrm{dm}^{3}$ (AB), $0.51 \pm 0.1 \mathrm{mg} / \mathrm{dm}^{3}$ (MS), $0.35 \pm 0.07 \mathrm{mg} / \mathrm{dm}^{3}$ (BZ), $0.32 \pm 0.06 \mathrm{mg} / \mathrm{dm}^{3}$ (CJ), $0.13 \pm 0.07 \mathrm{mg} / \mathrm{dm}^{3}$ (SJ) (table 5).

Although, the results by statistically point of view do not indicate significant differences (ns $\mathrm{P}>0.05$ ) between waterbodies monitored, are found closer individual values in analyzed samples from SJ where the values varies between 0.09 $-0.23 \mathrm{mg} / \mathrm{dm}^{3}$, compared with the other counties and samples taken into analysis. In terms of the values obtained at samples taken from different areas of Cluj, this county occupy the second place: $0-1.66 \mathrm{mg} / \mathrm{dm}^{3}$, mean: $0.32 \pm 0.06 \mathrm{mg} / \mathrm{dm}^{3}$. For waterbodies from the limitrophe areas of $\mathrm{AB}$ counties: $0.24-0.8 \mathrm{mg} / \mathrm{dm}^{3}$, BZ: $0.17-0.70 \mathrm{mg} /$ $\mathrm{dm}^{3}$, MS: $0.03-0.99 \mathrm{mg} / \mathrm{dm}^{3}$ individual values have wide ranges. Though this parameter is not regulated by law $485 / 2002$ it was taken into account because of action much more toxic than the ammonium ion and because in "the guide for completing the inspection notes concerning animal protection and welfare" is awarded notes for water quality dependent on certain physical, chemical parameters, ammonia being one of these. For note 5, this parameter would need to be absent in water and for note 3 the ammonia to have at the most $0.50 \mathrm{mg} / \mathrm{dm}^{3}$. Therefore, in terms of this parameter 4 from 6 samples exceed the value of 0.5 $\mathrm{mg} / \mathrm{dm}^{3}$ in $\mathrm{AB}$ (0.6-0.8 mg/dm $\left.{ }^{3}\right), 7$ (63.63\%) from 11 samples taken of the same number of wells in MS (0.51-1.90 mg/dm ${ }^{3}$ ). Though, does not exist significant differences between mean/counties, but the percentage of water samples which exceed the limit value is higher in counties: $A B(57 \%-4)$ and MS (63.63\%). Good results were obtained in samples taken from BZ, where $83 \%$ have values under $0.5 \mathrm{mg} / \mathrm{dm}^{3}$ these falling between $0.17-0.44$ $\mathrm{mg} / \mathrm{dm}^{3}$, CJ with $76 \%$ from samples under 0.5 (0.0$0.5 \mathrm{mg} / \mathrm{dm}^{3}$ ) and $100 \%$ from analyzed samples in SJ have results below this limit:0.09-0.23 mg/ $\mathrm{dm}^{3}$. By point of view of this parameter, only $62 \%$ of samples fall into good water for cattle of which value are found under 0.3 : 1 wells $\mathrm{AB}(0.24 \mathrm{mg} /$ $\mathrm{dm}^{3)}$, 3 wells BZ (0.17-0.3 mg/dm $\left.{ }^{3}\right), 19$ wells from CJ $\left(0-0.3 \mathrm{mg} / \mathrm{dm}^{3)}\right.$ and 4 wells from MS (0.03-0.3 $\mathrm{mg} / \mathrm{dm}^{3)}$.

Chlorides and sulfates. By statistical point of view was not found differences (nsP>0.05) between the samples from studied counties at parameter chloride, indicator of saline intrusion (table 6). Closer values are found in the water sampled from BZ, where, the values extend for between $55-145 \mathrm{mg} / \mathrm{dm}^{3}$ and SJ: $21-84 \mathrm{mg} / \mathrm{dm}^{3}$. In counties: CJ: $13-340 \mathrm{mg} / \mathrm{dm}^{3}$, MS: $21-1,890 \mathrm{mg} /$ $\mathrm{dm}^{3}$ it is notice a greater variation of results at this parameter, likewise in $A B$, where the variability of

Tab. 5. Mean obtained to parameter $\mathrm{NH}_{3} /$ counties

\begin{tabular}{|c|c|c|c|c|c|c|c|c|c|}
\hline \multirow{2}{*}{ 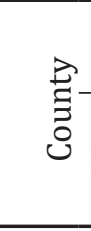 } & \multicolumn{5}{|c|}{$\begin{array}{c}\text { Value of ammonium parameters } \\
\text { (Kruskal-Wallis Test) }\end{array}$} & \multirow{2}{*}{ 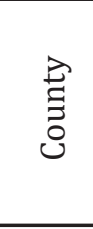 } & \multicolumn{3}{|c|}{ Fisher's Exact Test } \\
\hline & No.S. & $\begin{array}{l}\mathrm{X} \pm \mathrm{sem} \\
\mathrm{mg} / \mathrm{dm}^{3}\end{array}$ & Med. & Min. & Max & & $\begin{array}{c}\text { Samples\% } \\
\text { Under } 0.5 \\
\mathrm{mg} / \mathrm{dm}^{3}\end{array}$ & $\begin{array}{c}\text { Samples \% } \\
\text { Over } 0.5 \\
\mathrm{mg} / \mathrm{dm}^{3}\end{array}$ & $P$ value \\
\hline $\mathrm{AB}$ & 7 & $0.56 \pm 0.08$ & 0.65 & 0.24 & 0.80 & $\mathrm{AB}$ & $43 \%(3)$ & $57 \%(4)$ & $0.0286, \mathrm{~s}$ \\
\hline $\mathrm{BZ}$ & 6 & $0.35 \pm 0.07$ & 0.31 & 0.17 & 0.70 & $\mathrm{BZ}$ & $83 \%(5)$ & $17 \%(1)$ & $0.1667, \mathrm{~ns}$ \\
\hline $\mathrm{CJ}$ & 33 & $0.32 \pm 0.06$ & 0.13 & 0.00 & 1.66 & $\mathrm{CJ}$ & $76 \%(25)$ & $24 \%(8)$ & $\mathrm{P}<0.0001$, es \\
\hline MS & 11 & $0.51 \pm 0.1$ & 0.14 & 0.03 & 0.99 & MS & $36.36 \%(4)$ & $63.63 \%(7)$ & $\mathrm{P}=0.0022, \mathrm{vs}$ \\
\hline SJ & 6 & $0.13 \pm 0.07$ & 0.10 & 0.09 & 0.23 & SJ & $100 \%$ & - & - \\
\hline \multicolumn{6}{|c|}{$\mathrm{KW}=10.763 ; \mathrm{P}=0.0294-$ significant } & Total & $62 \%(37)$ & $38 \%(20)$ & $\mathrm{P}<0.0001$, es \\
\hline
\end{tabular}

Legend:Alba (AB), Buzau(BZ), Cluj (CJ), Mures (MS), Salaj(SJ), Med. (median ), Kruskal-Wallis Test (KWt), No samples (No.S.), standard error of mean (sem) ,median (med) es- extremely significant, ns- not significant,ssignificant,vs- very significant 
the results is extremely high $32-1,570 \mathrm{mg} / \mathrm{dm}^{3}$. Though, the mean samples defines a saltwater in $\mathrm{AB}$ this fact is given by the large amount of chloride found in one sample $1,570 \mathrm{mg} \mathrm{Cl} / \mathrm{dm}^{3}$, and another, where value exceeded the accepted limits value being of $280 \mathrm{mg} / \mathrm{dm}^{3}$.Variation in individual values certify good chemical status of water in 5 from 7 samples analyzed: $32-156 \mathrm{mg} / \mathrm{dm}^{3}$. Mean value close to the maximum permissible limit were obtained also in samples taken and analyzed from MS $243.18 \pm 164.8 \mathrm{mg} / \mathrm{dm}^{3}$, where one sample had as a result $1,890 \mathrm{mg} / \mathrm{dm}^{3}$.

BZ county is classify like being the occupant of the third position in the top of waters with larger amounts of chlorides but the individual values do not exceed limits set by the law of drinking water $458 / 2002\left(250 \mathrm{mg} / \mathrm{dm}^{3}\right)$. Variation in individual values certify good chemical status of water in 5 from 7 samples analyzed: $32-156 \mathrm{mg} /$ $\mathrm{dm}^{3}$ ): $114 \pm 9.97 \mathrm{mg} / \mathrm{dm}^{3}$, the amount varying between: $89-145 \mathrm{mg} / \mathrm{dm}^{3}$. In CJ, even if the mean $85.50 \pm 18.60 \mathrm{mg} / \mathrm{dm}^{3}$ indicate good chemical status of water in terms of this parameter, in 5 by 33 samples were obtained values between: $280-340 \mathrm{mg} / \mathrm{dm}^{3}$. In SJ, variation of the results at chlorides parameter are smaller compared to other counties (95\% CI: 30.39-74.64), the mean/ county having a value of $52.5 \pm 8.59$. Good chemical status of water in terms of the chlorides parameter it is presented as follows: 5 from 7 wells in AB: 32$156 \mathrm{mg} / \mathrm{dm}^{3} ; 6$ of 6 wells BZ:81-145 mg/dm ${ }^{3}, \mathrm{CJ}$ 28 wells: $14-160 \mathrm{mg} / \mathrm{dm}^{3}$, MS: 10 of 11 wells: 21 $125 \mathrm{mg} / \mathrm{dm}^{3}$, SJ 6 of 6 wells: $21-84 \mathrm{mg} / \mathrm{dm}^{3}$. About 300,000 ha of Romania's surface are soils saline and alkaline (Sanda et al., 2013), so the water is enriched in chlorides in those areas. High chloride levels indicate a risk of salt toxicity, maximum

acceptable levels of chloride in water after Curran (2014), for dairy cattle is $1.600 \mathrm{mg} / \mathrm{dm}^{3}$, and for beef cattle $4.000 \mathrm{mg} / \mathrm{dm}^{3}$. Divers et al. (2008) considers that, the concentration of chlorides in water should not exceed $0.25 \%$ because can lead to decreasing of milk production, farmers from the affected areas having the same complaint.

Another followed parameter indicator of saline intrusion was sulfates, which in terms of results obtained indicate good chemical status of the analyzed samples, in ascending order values being: MS- $52 \pm 10.10\left(12-100 \mathrm{mg} / \mathrm{dm}^{3}\right)$; CJ-74.66 $\pm 11.39 \mathrm{mg} / \mathrm{dm}^{3}\left(10-200 \mathrm{mg} / \mathrm{dm}^{3}\right)$ and one samples from one wells by exceeding the allowed limit:307 mg/dm ${ }^{3}$ AB-89.28 \pm 11.17 (55-145 mg/dm ${ }^{3}$; BZ-109.5 \pm 4.48 (97-126 mg/ $\left.\mathrm{dm}^{3}\right)$; SJ-139 \pm 8.65 (116-173 mg/dm $\left.{ }^{3}\right)$, Statistical, between CJ county and SJ, also between MS county and SJ county can be notice differences distinct significant $\left({ }^{* *} \mathrm{P}<0.01\right)$ on sulfates parameter.

Of total number of wells, only 21 wells have the good chemical status of water, registering values falling within limits or not exceeding $20 \%$, located in limitrophe areas of counties: Cluj (12), MS (3), SJ (6).

Exceedance the limits for CCOMn, $\mathrm{NH}_{3}, \mathrm{Cl}$, shows that in $\mathrm{AB}$ not even a sample of 7 does not fall within limits, the same situation is found in BZ county, where, in all samples (7), the amount of iron exceeds limit. There have been exceedance at the parameters: $\mathrm{CCOMn}, \mathrm{NH}_{3}, \mathrm{Fe}, \mathrm{Cl}$, in $\mathrm{CJ}$ (21 samples), also in 8 samples of MS. The only area with good water, is Salaj, where the chemical status of the 6 wells fits within the limits of drinking water.

\section{CONCLUSION}

Tab. 6. Mean obtained to indicator parameters of saline intrusion Chloride and sulphates/counties

\begin{tabular}{|c|c|c|c|c|c|c|c|c|c|c|c|}
\hline \multirow{2}{*}{$\begin{array}{l}己 \\
\Xi \\
\Xi \\
\Xi\end{array}$} & \multicolumn{5}{|c|}{$\begin{array}{c}\text { Value on Chloride parameters } \\
\text { (Kruskal-Wallis Test) }\end{array}$} & \multirow{2}{*}{ 忌 } & \multicolumn{5}{|c|}{$\begin{array}{c}\text { Value on Sulphates parameters } \\
\text { (Kruskal-Wallis Test) }\end{array}$} \\
\hline & No.S. & $X \pm$ sem & Med. & Min & Max & & No.S. & $X \pm$ sem & Med. & Min. & Max \\
\hline $\mathrm{AB}$ & 7 & $330.42 \pm 208.8$ & 130.0 & 32.00 & 1570.00 & $\mathrm{AB}$ & 7 & $89.28 \pm 11.17$ & 88.00 & 55.00 & 145.00 \\
\hline $\mathrm{BZ}$ & 6 & $114 \pm 9.97$ & 119.5 & 55.00 & 145.00 & $\mathrm{BZ}$ & 6 & $109.5 \pm 4.48$ & 108.00 & 97.00 & 126.00 \\
\hline $\mathrm{CJ}$ & 33 & $85.50 \pm 18.60$ & 40.0 & 13.00 & 340.0 & $\mathrm{CJ}^{* *}$ & 33 & $74.66 \pm 11.39$ & 59.00 & 116.00 & 173.00 \\
\hline MS & 11 & $243.18 \pm 164.8$ & 81.0 & 21.00 & 1890.00 & $M S$ & 11 & $52 \pm 10.10$ & 49.00 & 10.00 & 307.00 \\
\hline SJ & 6 & $52.5 \pm 8.59$ & 50.0 & 21.00 & 84.00 & $S J$ & 6 & $139 \pm 8.65$ & 134.00 & 12.00 & 100.00 \\
\hline
\end{tabular}


Poor chemical status was recorded in all the wells in $\mathrm{AB}$ county, where, exceedances were found at the parameters: CCOMn $7.5-13.75 \mathrm{mg}$ $\mathrm{O}_{2} / \mathrm{dm}^{3}$ ), seldom at chlorides, 2 samples which has high and very high salinity: $280-1570 \mathrm{mg} / \mathrm{dm}^{3}$ and ammonia (0.34-0.8 $\mathrm{mg} \mathrm{O}_{2} / \mathrm{dm}^{3}$ ).

Nonconformities who cause the retrograding of chemical status of water from wells was found at iron parameter in BZ county.Values obtained from all samples exceeded the limit at least 50\% in all studied wells $\left(0.3-2.99 \mathrm{mg} / \mathrm{dm}^{3}\right)$.

Some of the farmers from CJ county are faced with deficiencies in water quality administrated to the cattle at the indicator parameters of saline intrusion. In 5 wells, the water is not proper by point of view of quantity of chlorides: 280$340 \mathrm{mg} / \mathrm{dm}^{3}$. Other exceedances were found at indicators of oxygen regime CCOMn where, in 13 from 33 samples, from the same number of wells were obtained results between 6.95-15 mg $\mathrm{O}_{2} / \mathrm{dm}^{3} ; 24 \%$ the analyzed samples exceed the quantity of $0.5 \mathrm{mg} / \mathrm{dm}^{3}$ to parameter ammonia: $0.34-1.66 \mathrm{mg} / \mathrm{dm}^{3}$ and in 3 samples it is notice nonconformities to iron parameter: $0.25-0.75 \mathrm{mg} /$ $\mathrm{dm}^{3}$.

The water of wells from MS county is rich in iron, exceedances found: $0.51-2.01 \mathrm{mg} / \mathrm{dm}^{3}$ being present in 7 of these; in 5 wells were found impurification with organic matter: $5.5-9.93 \mathrm{mg} /$ $\mathrm{dm}^{3}$, and water from one wells has high amoung of chlorides: $1890 \mathrm{mg} / \mathrm{dm}^{3}$. From the total number of wells (11), 7 wells have poor chemical status because of exceedances recorded at the one or more parameters.

By point of view of chemical status, good quality, it can be ascertained at all parameters monitored in 5 of 6 samples collected from the same number of wells in SJ county. In a single sample was observed a slight pollution of the aquifer to parameter CCOMn: $5.01 \mathrm{mg} \mathrm{O}_{2} / \mathrm{dm}^{3}$, but being of a local nature and does not exceed $20 \%$ from accepted value water is considered good, therefore were not registered nonconformities at any of the studied parameters, the water is drinkable.

In terms of the hardness parameter, chemical status of water from decentralized water system is as follows: from 63 analyzed samples: 13 samples (21\%: CJ, MS) enroll in soft water, 7 samples (11\%: CJ, MS) semi-hard water (CJ MS), 35 samples (56\%:
$\mathrm{AB}, \mathrm{SJ}, \mathrm{BZ}, \mathrm{CJ}, \mathrm{MS})$ hard water and 8 samples $(13 \%$ : $A B, S J, C J, M S$ ) enroll invery hard water category.

Cannot speak of pollution of the analyzed samples results because of an exogenous sources of contamination of the aquifer but the lack of a proper hygiene of wells and disinfection, and the values at the parameters such as iron, saline intrusion indicators are dependent on the nature of the soil.

\section{REFERENCES}

1. Braul L, Kirychuk B, Willms W, Lardner B, Christensen D, Klemmer B, Corkal D (2001). Impotance of water quality to cattle, http://kellnsolar.com

2. Curran G (2014). Water for livestock: interpreting water quality tests, www.dpi.nsw.gov.au

3. Curran G, Robson S (2007). Water for livestock: interpreting water quality tests. PRIMEFACT 533 p.1- 5, www.ruralresidentialliving.com.au

4. Divers TJ, Peek SF (2008). Rebhun's Diseases of Dairy Cattle Ed. Saunders Elsevier

5. El Mahdy C (2013). Water hygiene and watering, p. 140-207.In: Zoo hygiene. Vol I "Natural environmental factors and influence on animal organism: beneficial and unfavorable action" ed. Napoca Star

6. German D, Thiex N (2008).Interpretation of water analysis for livestock suitability, www. agbiopubs.sdstate.edu

7. Helsel DR, Hirsch RM (2002). Techniques of WaterResources Investigations of the United States Geological Survey. Hydrologic Analysis and Interpretation. Statistical methods in water resources, http://water.usgs.gov

8. Iacob O, Tudor A, Neamțu A, Cristea A (2012). Well water: contamination by nitrates and methemoglobinemia. Guide for family physicians, doctors and hygienists DSP population. Edition I. University Press „Carol Davila”, www.insp.gov.ro

9. Linn J (2013) Effects of high iron in drinking water of dairy cattle, www.dairystar.com

10. Man C (2007). Ecological animal husbandry. Principles, techniques, regulations, case studies. Ed.Risoprint,ClujNapoca

11. Moldovan C, Soare F, Dumitrache F,Iliescu S ,Gheorghiu I, Rotaru N, Costea F, Nistor C (2014). Synthesis of water quality in Romania in 2013. Water resources potential and technical uses for the year 2013: 1-429, www.rowater.ro

12. Muntean C, Negrea A, Lupa L, Negrea P, Ciopec M (2009). Groundwater quality control. Bulletin AGIR (2-3): 38-43

13. Olkowski AA. (2009). Livestock water quality a field guide for cattle, horses, poultry, and swine., www.agriculture. gov.sk.ca

14. Vasile S, Alexiu V, Stefanut S (2013). Saline alkali soils and vegetation in Romania. Its progress under the influence of drainage works. ECOS, Pitești, 16:51-54, www.ecosmagazine.com 
15. Swistock BR. (2012). Interpreting Drinking Water Tests for Dairy Cows, http://extension.psu.edu

16. Ward M H, deKok TM, et al. (2005). Workgroup report: Drinking-water nitrate and health--recent findings and research needs. Environ Health Perspect. 113(11): 1607 14.

17. Drinking Water Directive 98/83/EC

18. Guide drafting the annual report on state of the environment as required by European environmental status report (SOER) http://www.mmediu.ro, 2015

19. Law No 311 from 28 June 2004 for modifying and completing the Law no. 458/2002 regarding the drinking water quality

20. Law No 458/ 2012 regarding the drinking water quality, published in the Official Monitor, Part I.552 din $29 / 07 / 2002$

21. Order no. 119/2014 approving the Norms of hygiene and public health on the population's living environment, published in Official Monitor, Part I no. 127 from 21.02.2014

22. Order no. 31 from 13 january 2006 regarding the approval the handbook for modernization and development of Integrated Monitoring System in Romania (SMIAR) published in Official Monitor, No. 234, http://www.legex. ro

23. Order no.621/2014 regarding the approval threshold values for groundwater in Romania, http://lege5.ro

24. Order no.75 from 15 August 2005 approving the sanitary veterinary norm regarding the protection of farm animals published in Official Monitor, No. 776

25. www.anpm.ro

26. www.anpm.ro, 2010

27. www.ecotrust.ro, 2016

28. www.limnology.ro,2010

29. www.posmediu.ro

30. www.rowater.ro, 2013 